\title{
Top Ten Reasons Sen. Gillibrand's Bill is the Wrong Solution to Military Sexual Assault
}

\author{
CHARLES J. DUNLAP, JR.
}

\begin{abstract}
Over the years Congress has made plenty of efforts to "improve" the military justice system for a variety of reasons, but few matters have generated more offerings than did the Pentagon's report this past spring of an estimated 26,000 victims of "unwanted sexual contacts" in the armed forces. Some initiatives to address this very critical problem, like the bipartisan effort of Senators Barbara Boxer and Lindsey Graham, look promising; others, not so much.

However, none are as misguided as Sen. Kirsten Gillibrand's proposal. Indeed, it is hard to think of a proposal that could be more wrong for the military, and especially for the victims of sexual assaults.

Sen. Gillibrand wants to remove commanders from the military justice process and replace them with a new, 600-person bureaucracy which would have lawyers as the "deciders" in disciplinary matters involving sexual assault and other serious cases. Her proposal is based on a popular narrative that is filled with false impressions such as the notion that the majority of the estimated 26,000 victims are women (actually, 53\% are men); that military personnel do not "trust" their commanders (polls show they do); that the handful of foreign militaries who have removed their commanders have shown progress in combatting sexual assault (they have not); and that prosecutor-centric systems like the one Sen. Gillibrand wants to impose on the military are more successful than the military's in suppressing sexual assault (the evidence shows they are less so).

Most troubling is the fundamental lack of a real understanding in Sen. Gillibrand's proposal as to what solves problems in the armed forces. It is axiomatic in the military that everything important is commander-led. This is particularly true with respect to the matters of morale and discipline that are so central to the warfighting capabilities for which commanders - not lawyers - are ultimately responsible and accountable. Lawyers, even those thoroughly expert in the law and indisputably well-intentioned as those serving in the armed forces, simply do not, and could not, have the broader insights and experience that commanders acquire through years of leadership, and by bearing the grave burden of sending young Americans in harms' way to do the Nation's business. Commanders are uniquely and irreplaceably equipped to exercise disciplinary authority in what the Supreme Court recognizes as the military's "separate society."
\end{abstract}

This essay argues that combatting sexual assault through the military justice system is just too important to be anything other than commander-led, and offers ten reasons why Sen. Gillibrand's proposal will hurt not only the military's readiness and warfighting capability, but also sexual assault victims. In addition, it describes legislative initiatives that should be examined, but are not being considered by anyone in Congress.

\section{INTRODUCTION}

Over the years Congress has made plenty of efforts to "improve" the military justice system for a variety of reasons, but few matters have generated more offerings than did the Pentagon's report this past spring of an estimated 26,000 victims of "unwanted sexual contacts" in the armed forces. Some initiatives to address this very critical problem, like

\footnotetext{
Copyright (C) 2013 by Charles J. Dunlap, Jr.

* Major General, USAF (Ret.), Professor of the Practice of Law and Executive Director, Center on Law, Ethics and National Security, Duke Law School.
} 
the bipartisan effort of Senators Barbara Boxer and Lindsey Graham, look promising; others, not so much. However, none are as misguided as Sen. Kirsten Gillibrand's proposal.

Sen. Gillibrand thinks the "solution" to sexual assaults in the armed forces is to remove disciplinary authority from field commanders and give it to a new, $\$ 113$ million, 600person bureaucracy that she wants the Pentagon to create. It is hard to think of a proposal that could be more wrong for the military and especially for the victims of sexual assaults.

As will be expanded upon below, the attack on the military justice system is curious since the armed forces are hardly the epicenter of the blight of sexual assault in our society. Professor Rosa Brooks of Georgetown Law School points out the enormous scope of the problem in the civilian community by observing that "[a] 2010 study by the Centers for Disease Control (CDC) found that 18.3 percent of civilian women had been raped at some point in their lifetime, while 27.2 percent had experienced 'unwanted sexual contact.'" Indeed, the Pentagon survey found that 30 percent of women and 6 percent of men in the military indicated they experienced "unwanted sexual contact" prior to entry into the armed forces.

One would think, therefore, that a serious effort to address sexual assault would have Sen. Gillibrand and others starting by investigating why so many young people come to the military already victimized. Such an examination might start with the nation's colleges and universities, as they share the military's youthful demographic.

One might think, for example, that since women outnumber men on college campuses the research might show that sexual assault was a lesser problem at universities, but that does not seem to be the case. In fact, Professor Brooks and others believe the problem of sexual assault is even more pronounced on America's campuses than it is in the armed forces.

The numbers appear to support their conclusions. Although there are no figures for all "unwanted sexual contact" in terms of actual assaults, the Centers for Disease Control reports that since entering college an astonishing $19 \%$ of women have experienced the most aggravated form of unwanted sexual contact, that is, attempted or completed sexual assault. Given those statistics, it is unsurprising that Brooks concludes that "the military appears to have done a better job than most colleges of reducing the sexual assault rate and increasing women's willingness to report assaults to the authorities."

A very recent article in Princeton University's newspaper also seems to support Brooks' conclusion by describing a survey showing that $15 \%$ of its undergraduate women reported not simply experiencing the "unwanted sexual contact" of the Pentagon survey (which could include an unwanted hug mistakenly given by someone with no expectation that it would be perceived as "sexual") but actual "non-consensual vaginal penetration during their time at the University." Would not all this suggest that the military should be something of an example - as opposed to a target - in the nation's battle against sexual assault?

Apparently, however, Congress does not see it that way, as it has shown little appetite for confronting colleges or universities. This is tragic for sexual assault victims, especially considering how leniently some universities treat transgressors. Atlantic Magazine, 
reports that at Yale, of six students found to have committed "sexual misconduct" since January 1 st, 2013 , "only one was suspended." The magazine adds that "[f]our received a 'written reprimand' - a letter from the administration clarifying that Yale does not tolerate sexual misconduct - but [Yale took] no tangible disciplinary action.”

Exactly why Sen. Gillibrand and others in Congress berate the military's efforts yet tolerate "no tangible disciplinary action" for sexual assaults at a university that reaps hundreds of millions in Federal grants is hard to figure. Could it not do more? For example, why not suspend a university's eligibility for Federal largess pending the enactment of tough standards for dealing with sexual assault? Why not, as some have suggested, levy fines on institutions out of compliance with Title IX of the Education Amendments of 1972 ?

Of course, it is beyond dispute that any and every sexual assault needs to be addressed, whether it arises in the military, on college campuses, or anywhere else. For if we are inclined to believe the number she quotes so readily, it is quite noteworthy that neither Sen. Gillibrand nor any of her supporters have ever explained why the commander-led system she criticizes so much nevertheless showed a $44 \%$ decline in the number of estimated victims between 2006 and 2010 and, even with the recent uptick, still shows an overall decline since 2006.

In fact, the sharp increase recently seen in servicemembers willing to come forward under the current commander-led system to report sexual assaults is a major development as it clearly undermines the central pillar of Sen. Gillibrand's argument for her legislation, that is, that victims are afraid to report sexual assault.

If the Pentagon has already seen a $46 \%$ increase in reporting under the existing system, why do we need Gillibrand's change that would rip apart a system that is showing substantial improvement? As Sen. Claire McCaskill (an ardent supporter of victims' rights but opponent of Gillibrand's bill), put it, the "new statistics of drastically increased reporting [are] a strong indicator that retaining a limited role for commanders, while instituting historic, aggressive reforms, is the key for curbing sexual assaults."

But there is much more wrong with Sen. Gillibrand's idea. Indeed, reams can be written detailing why Sen. Gillibrand's proposal for the armed forces is so misguided, but for the busy reader, this essay limits the critiques to the top ten reasons.

\section{THE TOP TEN}

\section{1) It will unnecessarily hurt victims of sexual assault.}

Sen. Gillibrand wants to yank commanders out of the disciplinary process in favor of lawyers, but victims will find that even well-intentioned lawyers are less able to vindicate their claims than are commanders. Because American Bar Association rules dictate that prosecutors not pursue cases in the "absence of sufficient admissible evidence to support a conviction," lawyers gauge which cases to take to trial based upon whether or not they subjectively think juries will conclude that the admissible evidence meets the demanding "beyond a reasonable doubt" standard.

Military commanders, however, see things differently because they have a wider set of responsibilities, including maintaining the morale and discipline so essential to leading 
troops in combat. Thus, military law only requires them to find "reasonable grounds to believe that an offense has been committed" in order to send a case to trial.

This appears to be why in the recent case of Naval Academy midshipmen accused of sexual assault the commander referred the case to trial against the recommendation of a military judge who investigated the case. But under Gillibrand's proposal, the decision of a lawyer that the cases should not be pursued would have trumped the military commander's view that the case needed to be prosecuted.

The reality is that military commanders are more disposed to send allegations of sexual assault to trial than are many civilian prosecutors. Sen. McCaskill explains that "[n]o data has been offered to show that commanders decline to refer cases for court martial. Data does show that in the past two years, commanders referred 96 cases for court martial that prosecutors declined to pursue-meaning 96 victims had their day in court because of commanders."

Additionally, Gail Heriot, a professor of law at the University of San Diego and a member of the U.S. Commission on Civil Rights, reports a Fiscal Year 2011 study of rapes occurring in a civilian setting under circumstances where both civilian and military authorities had jurisdiction. She said that on "those occasions...in which the civilian jurisdiction took the lead, prosecution rates were 11 percent. In contrast, the military's prosecution rate was 55 percent." Yet Gillibrand wants the military to model itself after such a markedly less victim-responsive arrangement.

More generally, the military takes to trial $21 \%$ of all reported cases, while in the lawyerdriven civilian sector process - the kind of system Gillibrand wants to impose - only $19.5 \%$ of cases make it to the courtroom. While a $1.5 \%$ differential does not seem like a huge difference, when translated into real numbers, it is really significant. Scores of victims seeing their cases being pursued in the current, commander-led system would not see them being prosecuted in civilian courts.

In short, it is a mistake for anyone - but particularly rape victims - to think that a lawyercentric scheme will be as aggressive in pursuing their cases as the commander-led system Sen. Gillibrand wants to dismantle. It is sadly predictable that the prosecutions in the armed forces would fall to the civilian rates or even lower. Under Gillibrand's proposal, too many military sexual assault victims would perceive the system as failing them yet again.

\section{2) It will impose a civilian-like process that has shown utterly no sign that it is more successful (and often less successful) at preventing sexual assault than the military's commander-led system.}

Benjamin Franklin once observed that "an ounce of prevention is worth a pound of cure." As already suggested, the evidence shows that the military's commander-led criminal justice system has proven to be been far more successful at preventing sexual assault in the armed forces than has the prosecutor-centric civilian system that Gillibrand wants to impose on the military.

Specifically, in 2012, the Centers for Disease Control reported a survey that showed during the previous twelve months, $5.6 \%$ of women, and $5.3 \%$ of men suffered sexual violence in the civilian population. What makes these percentages even more appalling is 
that they do not include rape. When rape is added, for women it approximates to an overall rape and sexual violence rate of 6.7 percent.

If those percentages from the civilian community were applied to the armed forces, an estimated 77,000 sexual assaults would have to occur to equal the estimate as to what happened in civilian society. Yet the Pentagon report that Senator Gillibrand and her supporters rely upon actually estimates the much lower figure of 26,000 "unwanted sexual contacts" - far less than what the percentages from civilian society would project.

Inexplicably, Sen. Gillibrand wants to uproot the commander-led process that these statistics indicate is approximately three times more successful in deterring sexual assaults than the prosecutor-centric civilian system she wants the military to emulate. Professor Brooks may put it best when she says that:

[Sexual assault in the military] is a genuine and serious problem, but the frantic rhetoric may be doing more harm than good. It conceals the progress the military has made in developing effective sexual assault prevention and response programs, and it distracts us from the even higher rates of sexual violence in comparable civilian populations.

Brooks argues persuasively that the "military seems to be doing something right, since it has been able to bring sexual assault rates down below those prevalent in comparable civilian populations." The military is "doing something right" because its commanderled system works as well or better than the civilian model.

3.) It will remove commanders - who have direct responsibility for success in combat from taking tough action they need to take to maintain morale, good order and discipline, and it will shift accountability for sexual assaults away from them.

Because commanders are more focused on battlefield victories than they are concerned about courtroom victories, this gives them a different mindset about prosecutions than the military lawyers who Gillibrand wants to be 'the deciders' in sexual assault and other cases of serious crimes. Colonel Jeanne Leavitt, the first woman to command an Air Force fighter wing, made this clear in her testimony before Congress last June.

According to Senator Carl Levin, Leavitt "told our committee that she could 'absolutely see the scenario where a prosecutor may not choose to prosecute a case,' because of the uncertainty of a conviction, but that '[as] the commander, I absolutely want to prosecute the case because of the message it sends, so that ... my airmen understand that they will be held accountable.",

This is yet another illustration as to how the thinking of a military commander can markedly differ from that of a lawyer. Sending clear messages to troops is an essential attribute of effective military leadership, but Sen. Gillibrand's proposal deprives commanders of a powerful tool for conveying such messages. "Messages" from even the finest staff lawyers, just would not - and could not - fill the resulting void.

Sen. Gillibrand also does not seem to realize how important accountability is to an effective defense establishment, notwithstanding Colonel Leavitt's reference to it. If Sen. Gillibrand's proposal is enacted, commanders could rightly say sexual assault is the 
"lawyers" problem because they, not the commanders, would have control of disciplinary action.

Yet military lawyers, as talented and as hard working as they are, simply are not in nearly as strong a position to holistically address the many aspects of the problem of sexual assault as are commanders with disciplinary authority. Without disciplinary authority commanders become mere managers, but to address as serious an issue as sexual assault, commanders need to lead the disciplinary process and be accountable for it.

\section{4.) It fails to appreciate the purpose of military law, and the vital role commanders play in it.}

According to Sen. Gillibrand, she proposed her legislation not because it would be better for national security, but because, she claims, "victims have asked." No criminal justice system, in the military or anywhere, ought to be shaped by what accusers want. Quite the contrary, the Constitution's Bill of Rights, is based on protecting the citizenry against the accusatory powers of the state.

Moreover, a central failing of Sen. Gillibrand's proposal is that it does not reflect - or even recognize - the larger purpose of military law as compared to civilian jurisprudence. The Manual for Courts-Martial makes it clear that a purpose of military law is to "promote justice" as well as "to assist in maintaining good order and discipline in the armed forces," but all of this is done not to advance the interests of any individual or even group of individuals (short of the citizenry writ large) - however deserving. Rather, the purpose of military law is "to promote efficiency and effectiveness in the military establishment, and thereby strengthen the national security of the United States." Therein lies a key problem with Sen. Gillibrand's proposal.

Perhaps because Sen. Gillibrand, like many of her supporters, has no military service or related experience on her resume, her proposal and her statements in connection with it reflect almost no appreciation for the potential harm to the nation's security her bill could cause. She and her supporters seem to have forgotten that the Supreme Court has found that "no governmental interest is more compelling than the security of the Nation."

Commanders are keenly aware of this paramount government interest, and it gives them even more incentive to purge sex offenders from their units because of its obvious effect on morale and discipline so necessary for success in combat. This is why so many with actual military experience find it bizarre that Sen. Gillibrand thinks that there is some kind of "conflict of interest" in a commander taking action against a member of his or her unit.

Whatever an "interest" may be to a civilian like Sen. Gillibrand, to a commander and, indeed, all members of the military, there is - as the Supreme Court puts it, "no governmental interest is more compelling than the security of the Nation." Since the security of the nation is undermined by sexual assault because it destroys the comradeship among troops so essential to warfighting capability, the real "conflict" is between the commander and those whose criminal conduct is imperiling the overarching "interest" in the nation's security.

In truth, commanders have unique insights in this regard because, unlike any prosecutor, they have the enormous burden of preparing young women and men to go in harms' way 
and, if necessary, kill other human beings in the name of the state. There is nothing like it in our civilian society. As the Supreme Court puts it, "[t]he armed forces depend on a command structure that at times must commit men to combat, not only hazarding their lives but ultimately involving the security of the Nation itself."

That "command structure" upon which the armed forces must depend needs to be held inviolate because of the warfighting mission. In order to carry out that mission which is, as the Court cogently describes it, "to fight or be ready to fight wars should the occasion arise," disciplinary authority is essential and irreplaceable. When George Washington said that "discipline is the soul of an army" he was echoing thousands of years of military history in which every successful commander in virtually all conflicts of any significance had the exact authority Sen. Gillibrand wants to take away.

Indeed, the Supreme Court recognizes that "[n]o question can be left open as to the right to command in the officer, or the duty of obedience in the soldier." This is what is so dangerous about Senator Gillibrand's amendment. By removing disciplinary authority from commanders and giving it to lawyers far from the battlefield, a question is, indeed, "left open as to the right to command in the officer, or the duty of obedience in the soldier." This explains why almost every commander with authentic combat experience is so dead set against Sen. Gillibrand's scheme.

Those in Congress most experienced with military matters understand why combatexperienced commanders are so opposed. As Sen. Carl Levin, Chairman of the Senate Armed Services Committee, put it:

We cannot strengthen our efforts by weakening the authority of our commanders to act against sexual assault. Commanders were tasked again with making monumental those changes in military culture, from combatting racial discrimination in the 1950 s to ending "don't ask, don't tell" in 2011. If we are to accomplish the change in military culture that we all agree is central to combatting sexual misconduct and sexual assault, commanders are essential. We cannot fight sexual predators if we make it more difficult to try and convict them. And we cannot hold our commanders accountable for accomplishing the needed change in culture if we remove their most powerful weapon in the fight.

\section{5.) It removes commanders from the disciplinary process even though the overwhelming majority of members of the armed forces, and their families, give their commanders the highest ratings in the battle against sexual assault.}

Sen. Gillibrand's proposal is surprisingly indifferent to the support that the overwhelming majority of military members and their families have expressed for their commanders. According to the Pentagon's own survey:

- 88 percent of women and 94 percent of men gave their leadership the highest rating for making it "clear that sexual assault has no place in the military;"

- 80 percent of women and 88 percent of men gave their leadership the highest rating for "promoting a unit climate based on mutual respect and trust;" 
- 77 percent of women and 86 percent of men gave their leadership the highest rating for "leading by example" on this issue; and

- 73 percent of women and 85 percent of men gave their leadership the highest rating for "creating an environment where victims would feel comfortable reporting."

Similarly, a June 2013 poll by the Pew Research Center found that military households again, overwhelmingly - believed that the better way of handling sexual assault was for the military commander to handle the issue internally as opposed to Congress changing military law. More generally, the Pew poll found that: "[m]ost of those in military households $(63 \%)$ have confidence in military leaders to do the right thing in handling the problem of sexual assault." In other words, military households oppose Congress making any change in military law on this issue, not just Gillibrand's proposal.

The Gillibrand bill reflects a basic misapprehension of the wants and needs of those of the vast majority actually serving in today's military. Quite frequently the victims supporting Sen. Gillibrand's bill are referencing experiences from years if not decades ago. Although everyone is sympathetic for what might have occurred in the past, relevant and effective solutions to military sexual assault must to based on the current military, not the military of past.

People in today's armed forces - as well as their families - know that if there is a tough problem to be solved, the effort must be commander-led. That is the reality of military life in the $21^{\text {st }}$ century, and those serving know it. That is why they support their commanders, and do want Congressional "fixes."

6.) It is inconsistent with the public's opinion, which expresses vastly more confidence in military leaders than it does in any group of lawyers, including the Supreme Court.

Sen. Gillibrand's proposal to replace military commanders with lawyers as the "deciders" in sexual assault cases profoundly misperceives the attitude of the public towards military leaders relative to lawyers.

Among the general public - despite being subjected to a virtual avalanche of negative antimilitary publicity on this subject - the Pew Research Center poll from last August showed that $52 \%$ have a great deal (or a fair amount) of confidence in military leaders to handle the sexual assault issue correctly, while only $37 \%$ have confidence in Congress to do so. Further, that $37 \%$ cannot be interpreted as support for Gillibrand's bill because there are a plethora of Congressional offerings of which hers is just one.

What Sen. Gillibrand' proposal fails to recognize is that the American public simply has considerably more confidence in military leaders than it does lawyers. According to a 2012 Harris poll, no group of lawyers - including the leaders of the civilian justice system and its courts - rates higher than military leaders in the public's confidence. Similarly, another Pew poll shows that the public's favorable view of military leaders (71\%) far outstrips that of the Supreme Court (53\%) and Congress (27\%).

It is true that the landslide of negative, one-sided publicity has taken its toll, especially when a poll such as the one conducted recently by the Washington Post/ABC News asked its question in such a way as to invite answers favoring Sen. Gillibrand's bill (which it 
editorially supports). By casting the debate on Gillibrand's proposal as between the attractive characterization of "independent military prosecutors" and the perfunctory and dismissive characterization of the commander-led systems as simply "the usual chain of command" it is not surprising that the former was more popular.

Why did not the poll cast the current system more accurately as "experienced commanders schooled in the challenges of military leadership"? Or some other more even handed way? Why did not the poll mention that that prosecutor-centric systems take fewer cases to trial? Why did not the poll mention the cost? And should we not question a poll when the sponsoring organization has already expressed it editorial view?

Regardless, as Congresswoman Loretta Sanchez put it "lawyers will never carry the broad authority and legitimacy of a military commander." And that is as true among the general public as it is within the armed forces itself.

\section{7.) It will deprive commanders - unique in their experience and expertise - of a key tool in addressing sexual assault as a threat to military readiness.}

Military readiness is a matter best addressed by military leadership, not staff lawyers. This is especially so when dealing with the intricacies of something so linked to readiness as sexual assault. For example, while commanders know that any sexual assault is a tragedy regardless of the gender of the victim, they nevertheless must deal with the popular narrative that assumes that most military sexual assault victims are female.

To be clear, if we accept the Pentagon's extrapolation regarding the 26,000 oft-quoted number of estimated victims of "unwanted sexual contact" in 2012, the majority had to be what the New York Times calls "overlooked victims"-- men, not women. Although a 2010 survey conducted for the Air Force by the Gallup organization found that $61.3 \%$ of the men sexually assaulted were victimized by a female perpetrator, Gillibrand activist Susan Burke insists that the 2012 survey reflects "men raping men."

Commanders are best positioned to deal with this complexity while recognizing that women, though comprising a minority of the estimated victims, have shown themselves much more willing to come forward with allegations of sexual assault. (Despite comprising only $47 \%$ of the estimated sexual assault cases, women account for $88 \%$ of the unrestricted reports that can initiate prosecution.)

Statements by politicians and others that suggest that women will be victimized if they serve in the military generate a threat to readiness that commanders must address. Their assertions, however mistaken, will naturally discourage women from joining. The military simply cannot afford to 'write off' literally half the talent pool and expect to be ready to meet the demands of $21^{\text {st }}$ century warfare. In addition to the readiness issue, commanders may also believe - as experts do - that solving sexual assault against women in the ranks involves increasing their numbers, something that their aggressive stance against sexual assault can only help.

In other words, the commander-led system has the flexibility - and, the broader expertise - to respond to the greatest threats to readiness than does a prosecutor-centric system.

Sen. Gillibrand's proposal is flawed because the lawyers she wants to put in charge, (though no doubt expert legal technicians and earnest, competent officers) simply do not 
have the broad-based experience in managing the larger issues of morale, discipline, and - ultimately - readiness that those who bear the mantle of command routinely experience. Attorneys, to include military lawyers, are also regulated by professional guidelines designed for a civilian setting and which do not easily accommodate the complex leadership challenges occasioned by what the Supreme Court calls the military's status as "a specialized society separate from civilian society."

In this context a commander's broader experience in this "specialized society" permits a more nuanced and sophisticated application of disciplinary measures. And this is exactly what is needed in the fight against military sexual assault. For example, while the open service of gays in the military has, to date, been accomplished with relatively little turmoil under the commander-led disciplinary process Sen. Gillibrand wants to end, the upheaval caused by her bill could threaten that.

Challenges can still arise that demand a commander-led effort. Consider that one pundit has already claimed that "some evidence exists to substantiate the traditional concern...that open introduction of homosexuals into the military's intimate quarters will only aggravate sexual assault problems." Whether he is accurate or not, command leadership needs to be at the center of a disciplinary process that has to address, as Gillibrand activist Susan Burke put it, "men raping men."

Given the unusually sensitive political, social, legal, and operational issues associated with integration of gays openly serving in the military, it should be obvious that commanders - not staff lawyers - remain the ones best equipped to navigate and lead in this extraordinarily complex terrain. There simply could not be a worse time to remove commanders from their leadership position in the sexual assault disciplinary process than now.

Sen. Carl Levin, Chairman of the Senate Armed Services Committee, put it aptly:

We cannot strengthen our efforts by weakening the authority of our commanders to act against sexual assault. Commanders were tasked again with making monumental those changes in military culture, from combatting racial discrimination in the 1950s to ending "don't ask, don't tell" in 2011. If we are to accomplish the change in military culture that we all agree is central to combatting sexual misconduct and sexual assault, commanders are essential. We cannot fight sexual predators if we make it more difficult to try and convict them. And we cannot hold our commanders accountable for accomplishing the needed change in culture if we remove their most powerful weapon in the fight 
8.) It is in 'denial' about the fact that foreign militaries that removed the commander from the disciplinary process fail to show an increase in the number of sexual assault reports, and may have complicated prosecutions in a way that would be detrimental to the American military.

A cornerstone of Sen. Gillibrand's argument for removing commanders from the disciplinary process is that victims allegedly do not trust commanders and, therefore, would be more likely to come forward under a prosecutor-centric system. She cites the handful of foreign militaries that have removed commanders as examples of the scheme she wants to impose upon American troops. Of course, the polls of U.S. troops and their families noted above show clearly that they $d o$, in fact, trust their commanders, but as important on this issue is the data emerging about the foreign militaries she relies upon.

That evidence does not show that any of these foreign militaries have made any significant progress in halting sexual assaults. For example, "complaints of sexual harassment and assault in the [Israeli defense Forces] have increased by more than $80 \%$ in the past five years." Canadian activists insist that their military is suffering from the same problem with sexual assaults that the U.S, military is facing, and media reports show that the Australian military is likewise dealing a myriad of allegations. As to the U.K, the Complaints Commissioner for British forces conceded in 2012 that she was "still unable to say that the Service [sexual assault] complaints system is working efficiently, effectively or fairly."

More decisively, in a November 7, 2013 public hearing, the Response Systems for Adult Sexual Assault Crimes Panel established by Congress by Section 576 of the National Defense Authorization Act for Fiscal Year 2013 shows that Sen. Gillibrand is wholly mistaken about the impact of the removal of the commander from foreign military justice systems. Specifically, the panel said:

We...find that none of the military justice systems of our allies was changed or set up to deal with the problem of sexual assault, and none of them can attribute any changes in the reporting of sexual assault to changing the role of the commander. Lastly, we have seen or found -we have found no evidence that the removal of the commander from the decision making process of non-U.S. military justice systems has affected the reporting of sexual assaults.

Furthermore, the impact on discipline in the U.S. military of the foreign systems would be very real and manifestly adverse. Consider that none of those relatively small militaries Sen. Gillibrand and her cohorts cite as prototypes for the American military have world wide security responsibilities comparable in size and complexity with those of the U.S.

In addition, none has been able to demonstrate that its lawyer-centric systems (which often involve civilian lawyers) are realistically deployable to combat zones as none despite more than a decade of war in Iraq and Afghanistan - has managed to complete a single trial in a combat theater. This has serious implications for the ability of any military justice system to address sexual assault.

The U.S. does not - and cannot go down the path advocated by the Gillibrand activists because the U.S. needs a 'portable' military justice system that can hold accountable 
misbehavior in the field. As the Defense Policy Board concluded last May, while "good order and discipline [are] important and essential in any military environment, it is especially vital in the deployed environment. The military justice system is the definitive commander's tool to preserve good order and discipline, and nowhere is this more important than in a combat zone." It is that crucial tool that Sen. Gillibrand wants to take from the hands of the warfighters and give it to lawyers.

Additionally, because the foreign systems that Sen. Gillibrand lauds necessitate shipping miscreants home for criminal justice processing, it raises the obvious question: should sexual misconduct become an avenue out of a dangerous combat zone? Doing so erodes the deterrent value of having trials conducted in situ, and injures morale as the troops see accused get, in essence, a ticket home. Could it perversely incentivize sexual assault? We know that some soldiers can become so desperate to escape the terror of the front lines that they purposely injure themselves (hence the crime of malingering under military law). Could sexual assault become a new means of escaping a war zone? Do we want to find out?

It is also important to understand, as Sen. McCaskill clearly does, that those of "America's allies that removed chain of command from these cases did so to better protect the rights of defendants - not the rights of victims." In other words, if Sen. Gillibrand wants America to mimic foreign justice systems, doing so may well make it more, not less, complicated to vindicate victim's charges, especially if the other features of foreign law are adopted. To be sure, we need to examine foreign law for possible good ideas, but it is simply incorrect to assume that these foreign countries facilitated sexual assault prosecutions by removing the commander from the disciplinary process.

In summary, there is zero evidence that removing the commander from the disciplinary process has done anything to help address the sexual assault problem in foreign militaries. Furthermore, these countries are left with highly civilianized military justice processes that have not demonstrated the world-wide utility of America's commander-led system. What is crucial is that the U.S. military justice is effective in the vital deployed environment mainly because of the very commander involvement and focus that Sen. Gillibrand's bill would eliminate.

\section{9.) It will unnecessarily cost the military millions in scarce dollars, and will drain needed legal resources away from troops and their families.}

It is a surprise to no one that the military is suffering from the unprecedented effects of sequestration and other budget cuts. That said, everyone would gladly spend the money to fund Sen. Gillibrand's bill if it could really help military solve anything. The main problem is that it will not help; it will actually hurt the military's efforts to combat sexual assault.

Plus, the cost to troops and this families for Sen. Gillibrand's program is very real. According to General Ray Odierno, the Chief of Staff of the Army, Gillibrand's bill is "detrimental to the military," and it would also cost the Army "millions." As already noted, informed estimates put the cost at $\$ 113$ million for a staff of 600 lawyers and support personnel. Because there are no additional resources with her bill, the military will have to cut other programs to pay for it and to man it if enacted. 
$\$ 113$ million may not seem like much to some, but to military families, it matters a lot. For example, the National Military Family Association says that sequestration is forcing a "\$106 million in cuts in Impact Aid money that supports civilian schools educating military kids" Would it not be better to help the hundreds of thousands of military children than it would be to waste money on an unneeded and counterproductive bureaucracy?

Media reports also point out that commissaries, which are used by hundreds of thousands of active duty, retired, and National Guard personnel and their families, are suffering a $\$ 70$ million cut. It is uncertain what additional cuts the military would need to make to fund Gillibrand's bureaucracy, but what is clear is that in today's military, $\$ 113$ million is real money, and that military families are the ones who will likely pay the price. Again, should not our military households - who polls say do not want Congress changing military law - be considered?

What is more is that in an era of highly-constrained resources, Gillibrand's bill does not provide for any additional military manpower for the 600-person lawyer-laden edifice she wants to build, and inevitably that will leave fewer military lawyers available for other duties. Make no mistake about it, the manning issue is a genuine issue for the military services. For example, 600 people represent about half of the entire legal capacity of the whole Marine Corps - officer and enlisted.

Put plainly, Sen. Gillibrand's bill would mean fewer military lawyers would be available to counsel young servicemembers and their families on legal problems, fewer military lawyers to oversee multi-billion dollar procurements, and fewer military lawyers available to provide advice for warfighting commanders to ensure our actions are in compliance with international and domestic law. It cannot be overstated how valued military lawyers are to a range of essential duties, so their loss would be a serious blow to the clients on their already full agendas.

Moreover, those diverted resources do not even address the fact that the demands of the new bureaucracy would mean that fewer seasoned prosecutors, experienced defense attorneys, and victims' attorneys with military justice expertise would be available to actually work on these cases. Quite clearly, morale, discipline of the overwhelming majority of military members as well as the military effectiveness of our armed forces would suffer.

\section{0.) It is too tainted by bad data and the activities of "Washington-based advocacy groups with limited membership, participating in personal attacks, [and who] do not represent the views of all [sexual assault] survivors."}

Unfortunately, Sen. Gillibrand has relied upon bad data in making her proposal. For example, she credits the movie "Invisible War" with "shaping" her bill. However, experts have found it to be riddled with inaccuracies and unsupportable claims. One questioned whether it is "uninformed, dishonest, or both?" Most importantly, it has been slammed by some rape victims - yet it continues to be a centerpiece of the promotional efforts by Gillibrand's supporters.

Interest groups have also distorted what should have been an open dialogue of all points of view. Regrettably, backers of Sen. Gillibrand's bill include what Sen. Claire McCaskill characterizes as "Washington-based advocacy groups with limited 
membership, participating in personal attacks, [and who] do not represent the views of all [sexual assault] survivors." It is not surprising that such well-funded groups have inundated Congress with all kinds of propaganda, including much that could most charitably be described as "misleading."

Furthermore, McCaskill's reference to "personal attacks" is not an idle claim. Recently, Gillibrand advocates have sought to muzzle those within the armed forces who believe that a commander-led system better protects victims and would better preserve morale and discipline. What is disingenuous about that effort - which had no legal basis - is that Sen. Gillibrand herself says that the basis for her attack on the military justice system is what she says she heard from active duty victims. Should she not then also listen to those on active duty who think the commander-led system does do a better job for victims? Why try to muzzle those who disagree?

Perhaps Sen. Gillibrand and her supporters fear that as more facts emerge, and more analysis is obtained, the flaws in her proposal will become better known. This can be seen as she and her supporters are frantically trying to get legislation passed before a Congressionally mandated panel completes its work. As one observer put it: "[i]n what seems like a case of ready-fire-aim, Congress is rewriting military sexual-assault laws and policies without waiting for the recommendations of an expert panel that lawmakers themselves once deemed necessary.”

What is particularly disturbing is that the data that Sen. Gillibrand claims supports her proposal has become increasingly discredited. Lindsay Rodman, a brilliant young Marine captain with first-hand knowledge of how the Pentagon survey was conducted (which underpins Sen. Gillibrand's contentions about the military justice system), has ripped its methodology in her Wall Street Journal op-ed. This Harvard-educated lawyer said "It is disheartening to me, as a female officer in the Marine Corps and a judge advocate devoted to the professional practice of law in the military, to see Defense Department leaders and members of Congress deal with this emotionally charged issue without the benefit of solid, verifiable data."

Likewise, Paul Lavrakas, the president of the American Association for Public Opinion Research, was "troubled that three years of survey data produced such different estimates" and added that when "you see them jump around like that, the first thing that comes to mind is there's something wrong with the numbers." Because of the flawed data, Captain Rodman rightly fears that solutions from Capitol Hill "will only make things worse" for sexual assault victims.

\section{NeEDED LEGISLATION THAT No ONE IS PROPOSING}

It is true that the fight against sexual assault would benefit from new legislation, and Congress could start with fixing the current law criminalizing sexual assault. Unfortunately, Congress's recent record of tinkering with military sexual assault law is hardly encouraging. Its 2006 revision was so badly botched that one military judge quipped "If you had 100 monkeys with a typewriter, they'd probably come up with something like this." Unsurprisingly, the all-civilian Court of Appeals for the Armed Forces gutted the law on Constitutional grounds.

The next effort - which came into effect in 2012 - is also proving problematic. Disappointingly, Congress did not adopt the clear and easily understood definition of 
rape that the Department of Justice announced (also in 2012): "The penetration, no matter how slight, of the vagina or anus with any body part or object, or oral penetration by a sex organ of another person, without the consent of the victim." Instead, Congress imposed on the armed forces a complicated definition that, unlike the modernized Department of Justice definition, did not include "without consent."

Thus, consent - as well as mistake of fact as to consent - is virtually eliminated as a defense in military cases, even though civilian jurisdictions typically provide just such a legal justification for sexual behavior. Military judges and others have tried various approaches to try to breathe a "consent" defense back into the law in an effort to preserve its legitimacy, but it remains to be seen if doing so is really Constitutional in the face of an explicit Congressional excision, as such judicial 'legislating' may - among other things - violate separation of powers doctrine.

Besides eliminating consent as a defense to sexual assault, Congress also eliminated the sexual component to certain constructs of what is chargeable as "rape." For example, unlike the Department of Justice definition which criminalizes a form of rape as oral penetration "by a sex organ," the definition Congress imposed upon the military defines the sexual act as including "the penetration, however slight, of the ... mouth of another... by any object."

The kind of intent required for completion of the elements of this form of "rape" under current military law is not something related to sexual gratification (or some other sexually-related mindset) as one might expect (and as is implicit in the Department of Justice definition), but with the sexually-neutral intent "to abuse, humiliate, harass, or degrade any person."

What does all this mean? Factual situations manifestly underserving of characterization as the serious crime of "rape" could nevertheless be so designated because of flaws in Congress's 2012 law. This does a real disservice to victims of rape (that is, as defined by the Justice Department), and the Gillibrand bill does nothing to remedy it.

For example, because of the "any object" language Congress put in the military definition of rape (as opposed to the "sex organ" language in the Department of Justice definition for rape involving oral penetration) someone throwing a pie in another's face is a "rapist" if any portion of the pie penetrates the "mouth," and it was thrown "with an intent to abuse, humiliate, harass, or degrade any person."

Because of the lack of any required sexual intent, if today's military law were in effect at the time and applicable to the perpetrators, it would make such improbable people as G. Gordon Liddy, Bill Gates, and (opponent of Sen. Gillibrand's bill) Sen. Carl Levin, all "rape" victims because all were targets of a thrown pie. Is not calling this kind of behavior "rape" denigrating to true victims of the crime?

Think it could never be charged? Actually, there is no telling what prosecutors might charge. The Supreme Court is currently considering a case where a jilted wife is being charged with using a "chemical weapon" on her husband's lover in contravention of Chemical Weapons Convention. A weapon of mass destruction? Not exactly given that the extent of victim's injury was a simple thumb burn that was "treated" with "running water in the sink." 
Nevertheless, this charge - which under state law would amount to little more than simple assault - was pursued by a Federal prosecutor under a similar system as that proposed by Sen. Gillibrand for the military. Additionally, if the law Congress imposed on the military in the 2012 law had been in effect in 1945, the sailor pictured in the iconic photo kissing the nurse in Times Square at the end of World War II could have found himself charged as a "rapist." Boorish and even assaultive behavior? Maybe. But rape?

Clearly, it should not be possible for sexual assault victims, and particularly rape victims, to have their suffering trivialized by such an overbroad statute. Indeed, it is insulting to them. Yet Gillibrand's bill does nothing to correct the obvious faults in current law.

Again, legislating the Department of Justice definition into the law would provide the clarity commanders and their military lawyers need to explain the prohibitions to the troops. It would also eliminate any ambiguity that might allow a rapist to escape punishment because of action an appellate court may find it needs to take on Constitutional grounds.

In addition, any legislation needs to ensure that those accused have their civil liberties protected, something that Sen. Gillibrand seems to overlook in her claim that her proposal is based on what accusers want. This is a special concern given reports of rising numbers of false accusations in the military. Unhappily, the system that Sen. Gillibrand wants the military to copy has produced hundreds of convictions which were proven wrongful by advances in DNA technologies.

What is more is that in the civilian setting people of color, to include principally AfricanAmericans, have been disproportionately wrongly convicted by the kind of prosecutorcentric system Sen. Gillibrand wants for the military. Consider that African-Americans encompass just $13.6 \%$ of the U.S. population, yet FBI statistics show that they comprise $32.9 \%$ of those arrested by civilian authorities for forcible rape. Even though AfricanAmericans are nearly three times more likely to be arrested by the kind of prosecutorcentric system Sen. Gillibrand wants for the military, it is also important to understand that they make up $61 \%$ of those exonerated by the Innocence Project (and another 9\% are other people of color).

Military commanders are keenly attuned to threat of racial discrimination for many reasons. They know how critically important for morale and discipline - and, indeed, victory in combat - it is to ensure that unlawful discrimination does not devastate the comradeship and unit cohesion that military success requires. The imperative to keep the system free from discrimination is not simply a philosophical, idealistic, or legal requirement as it may be for Gillibrand's proposed bureaucratic edifice; it is a matter of warfighting necessity for military commanders.

Finally, Congress ought to toughen the penalty for rape. It softened that penalty - to include even for child rape - by eliminating the death penalty even though it is not clear that doing so was Constitutionally mandated. There is a strong case to be made that retention of the death penalty for rape is crucially important for the armed forces because courts-martial may need to be used to try war criminals, to include especially those in an enemy force.

We have long known that rape in a wartime setting can involve motivations that could be very different than those that arise in a domestic, criminal law context. What makes 
Congress' relaxing of the penalties so frustrating is that they come at a time when we are seeing America's enemies increasingly using rape as a weapon of war. Congress needs to restore the death penalty to military law so that it would be available, for example, for possible trials of future enemy war criminals. The death penalty could serve as a powerful deterrent to the use of rape as a weapon of war and, even if not deterring, it can serve justice for victims of such a horrific crime.

Instead of focusing on these urgently needed reforms, Sen. Gillibrand's bill does nothing to address them. This is yet another reason why even those who believe the military justice system needs amendment ought to appreciate that any change must be the product of thoughtful, considered study and analysis (as is underway now by the panel Congress established) not simply highly-politicized machinations.

\section{FINAL OBSERVATIONS}

Military leaders know that taking the commander out of this disciplinary process will inevitably harm the warfighting effort. In 1947 then General Dwight D. Eisenhower warned about giving military justice authority to staff officers when he insisted that "there must be someone that is in the chain of responsibility, or the men in the field are not going to take it and like it." He further warned (uncannily presciently given Sen. Gillibrand's desire to substitute staff lawyers for commanders) that if "some staff officer with no responsibility for winning the war, who is not even subject to the supervision of the Secretary of War for the handling of this thing" acted in a military justice matter, "there is going to be resentment-and very deep resentment. I assure you there will be." This is as true today as ever.

Sen. Gillibrand's proposal is also flawed because it supposes that we can "prosecute" our way to a solution for sexual assault so endemic in society in general. We tried that approach with War on Drugs only to find, as Attorney General Holder recently said, that while we can be "coldly efficient in jailing criminals" our nation nevertheless simply "cannot prosecute or incarcerate" its way to personal safety. Let us not make the same mistake with the scourge of sexual assault.

In what is perhaps the most thoughtful commentary on this complex issue, Captain Rodman argues that what is needed is a "constructive dialogue on military sexual assault" and one that embraces the "gray areas." This is needed, she says, to "shift the focus of the conversation away from the current self-perpetuating cycle of encouraging further prosecution to address a frustrating conviction rate." Regrettably, that conversation is not taking place in Congress. As Rodman says, "[t]he agenda should be to identify the problem, to come up with a solution" and adds "That's not what I see happening right now."

To be sure, the ongoing Congressionally-mandated study will likely yield recommendations for changes in the military justice system. But until they have the opportunity to complete their work, there is no reason to jeopardize the ability of commanders to "provide for the common defense" through precipitous legislation that by its sponsors own assertion is not based on that most basic imperative. We must be sure we understand the unintended consequences of even the most well-meant law. The security of the nation demands it. 